\title{
Dietary Assessment and Self-Management Using Information Technology in Order to Improve Outcomes in Kidney Transplant Recipients
}

\author{
Fernanda G. Rodrigues ${ }^{1,2}, *\left(\mathbb{D}\right.$, Martin H. de Borst ${ }^{2} \mathbb{C}$ and Ita P. Heilberg ${ }^{1,3}$ \\ 1 Nutrition Post Graduation Program, Universidade Federal de São Paulo, São Paulo 04023-900, Brazil; \\ ita.heilberg@gmail.com \\ 2 Department of Nephrology, University of Groningen, University Medical Center Groningen, \\ 9713 Groningen, The Netherlands; m.h.de.borst@umcg.nl \\ 3 Nephrology Division, Universidade Federal de São Paulo, São Paulo 04023-900, Brazil \\ * Correspondence: fernanda.gr91@gmail.com
}

Received: 7 October 2020; Accepted: 13 October 2020; Published: 1 November 2020

\begin{abstract}
Big data and artificial intelligence (AI) will transform the way research in nephrology is carried out and consequently improve the performance of clinical practice in nephrology and transplantation. Managing long-term health outcomes in kidney transplant recipients (KTR) includes the improvement of modifiable factors, such as diet. Self-management using information technology (IT) aims to facilitate lifestyle changes, manage symptoms and treatment in the course of chronic kidney disease (CKD) or any chronic condition. The advantages of health mobile applications further include the capacity of data compilation and yielding responses to numerous research questions in nephrology and transplantation. However, studies investigating the employment of such applications in KTR and its impact in kidney transplant outcomes are still lacking. The specific advantages of dietary assessment and self-management using IT in order to improve outcomes in KTR are presently discussed. This Special Issue features a great set of articles regarding IT approaches to improve kidney allograft survival and posttransplant outcomes in all areas.
\end{abstract}

Keywords: kidney transplantation; nutrition; self-management; information technology

Kidney transplantation is considered the preferred treatment for most patients with end-stage renal disease (ESRD) [1] in view of the improved quality of life, survival rates and cost-effectiveness in comparison to chronic dialysis treatment [2]. Notwithstanding the advance in overall one-year kidney allograft survival brought by innovative surgical techniques and immunosuppressive protocols [3], the survival of kidney transplant recipients (KTRs) continues to be significantly lower than individuals of a similar age in the general population [4].

Managing long-term health outcomes in KTR includes the improvement of modifiable factors such as diet. Although specific dietary recommendations for KTR are still lacking [5], recent large cohort studies have disclosed novel and interesting findings that assist the comprehension and attainment of new knowledge regarding nutrition and post-transplant outcomes [6-9]. The adherence to dietary patterns, such as DASH (dietary approach to stop hypertension) and Mediterranean diet, has been positively associated with better kidney graft outcomes and lower risk of all-cause mortality $[7,8]$. Large KTR cohort studies investigating specific food groups have demonstrated that the intake of fish, known to be rich in omega-3 fatty acids, was inversely associated with risks of long-term cardiovascular and all-cause mortality [6,10]. Moreover, vegetable intake was associated with a lower risk of post-transplantation diabetes mellitus and cardiovascular mortality [9]. Weight gain and other 
metabolic comorbidities are frequent in KTR [11] and have been associated with graft loss [12]. These findings shed light on the importance of adequate nutrition after transplantation.

Recently, a qualitative study in KTR by Boslooper-Meulenbelt et al. [13] has reported the lack of food literacy as a barrier to a good-quality dietary pattern, emphasizing the importance of accessible and understandable nutritional interventions following kidney transplant. Furthermore, the authors emphasize that specific attention for dietary transition barriers is required for KTR, especially considering their previous dietary restrictions imposed by chronic kidney disease (CKD). Self-management using information technology (IT) aims to facilitate lifestyle changes, manage symptoms and treatment in the course of CKD or any chronic condition [14]. Several health-related mobile applications contain functionalities that are effective and highly promising for nutrition-related health outcomes [14,15]. A study performed in CKD patients used a web application to help individuals in pre-dialysis, in dialysis and posttransplant to make decisions according to diet restrictions and phosphate binder dosage [16]. The results of this research have shown that this application increased the patients' insight and understanding related to an appropriate CKD-specific diet, besides improving the ability to provide decision support regarding diet and binder intake [16]. A study evaluating twenty-one renal diet-related mobile applications disclosed that the technical quality and health literacy demand of the apps were acceptable, although more than half of the apps did not contain accurate, evidence-based renal diet information [17]. The most important characteristics of a renal diet tailored to KTR should consist of an adequate energy to prevent either protein-energy wasting or overweight/obesity; adequate protein intake to improve quality of life and survival rates, to better control serum phosphorus and ameliorate lipid profile; phosphorus intake to avoid hyperphosphatemia in the late period post-transplantation, which in turn leads to or worsens pre-existent CKD-MBD (mineral bone disorder); adequate potassium intake to reduce the risk of hyperkalemia, associated with cardiac arrhythmia and sudden death; control of sodium intake to avoid increases in blood pressure and cardiovascular risk [18]. The suggested modifiable dietary elements in post-kidney transplantation are summarized in Table 1. Kosa et al. [19] have demonstrated in a systematic review that a mobile application with focus on engaging patients and encouraging healthy self-management of CKD was beneficial to ameliorate the adherence to dietary restrictions pertaining to sodium, potassium, phosphorus, protein, calories, and fluid.

Recently, the employment of mobile health technology application aimed at managing and monitoring medication for KTR has proved useful for these patients [20]. However, it seems that the quality of online information for transplant health care still needs improvements [21]. A recent clinical trial has shown that a web-based intervention with individual telemedicine couching for three months was able to cause reduction in dietary sodium in CKD patients, including KTR, when compared to regular routine care [22]. Despite the foreseen advantages of a better control of food intake by KTR, there are only a few studies investigating the use of a dietary self-management application in KTR to date.

Besides intervention, the advantages of health mobile applications should include the capacity of data compilation. A recent review has disclosed that the methods for dietary assessment using technology has several advantages, encompassing the use of minimal resources and cost-savings, the enhanced veracity of dietary intake reports, besides more engagement and feedback from patients [23]. Given that more than half of the global population is currently connected to the internet, the usage of electronic health records can empower the patients in their dietary decision-making process, and in exchange, contribute to the development of large datasets that can be used by researchers to answer numerous pertinent research questions in nephrology and transplantation, as exemplified above. In recent years, the artificial intelligence (AI) field has substantially changed the way digital data are analyzed and used [24], and it will similarly transform the way research in nephrology is carried out, improving clinical practice in nephrology and transplantation [25]. For this to happen, future AI models must be integrative, gathering diversified data to provide superior accuracy and tenacity [24]. 
This Special Issue presents a great set of articles regarding IT approaches to improve kidney allograft survival and posttransplant outcomes. Further prospective and multi-center validation studies are needed to fully elucidate how KTR can benefit from IT use, particularly in relation to functionalities targeted to facilitate dietary self-management tasks. Future research is also required to enlighten how IT applications in KTR can be translated into improvements in clinical outcomes in post-transplantation.

Table 1. Suggested modifiable dietary elements for a post-kidney transplant in metabolically stable patients with preserved graft function.

\begin{tabular}{ll}
\hline Energy & $\begin{array}{l}\text { Energy consumption must be maintained between } 25 \text { and } 35 \mathrm{kcal} / \mathrm{kg} \text { body weight per day } \\
\text { based on age, sex, level of physical activity, body composition, weight status goals and } \\
\text { eGFR level. }\end{array}$ \\
\hline Protein & $\begin{array}{l}\text { Protein intake must be adjusted according to graft function and eGFR level. The amount of } \\
\text { dietary protein intake may vary between } 0.55 \text { and } 1.0 \mathrm{~g} / \mathrm{kg} \text { body weight per day. }\end{array}$ \\
\hline Phosphorus & $\begin{array}{l}\text { Dietary phosphorus intake must be adjusted to maintain serum phosphate levels within the } \\
\text { normal range. }\end{array}$ \\
\hline Potassium & $\begin{array}{l}\text { Dietary potassium intake is aimed to maintain serum potassium within the normal range } \\
\text { and has to be adjusted according to eGFR level. }\end{array}$ \\
\hline Sodium & Sodium intake must be adjusted to less than $100 \mathrm{mmol} / \mathrm{d}$ (or $<2.3 \mathrm{~g} / \mathrm{d})$. \\
\hline & eGFR-estimate glomerular filtration rate.
\end{tabular}

Funding: This research received no external funding.

Conflicts of Interest: The authors declare no conflict of interest.

\section{References}

1. Abecassis, M.; Bartlett, S.T.; Collins, A.J.; Davis, C.L.; Delmonico, F.L.; Friedewald, J.J.; Hays, R.; Howard, A.; Jones, E.; Leichtman, A.B.; et al. Kidney Transplantation as Primary Therapy for End-Stage Renal Disease: A National Kidney Foundation/Kidney Disease Outcomes Quality Initiative (NKF/KDOQI ${ }^{\mathrm{TM}}$ ) Conference. Clin. J. Am. Soc. Nephrol. 2008, 3, 471-480. [CrossRef] [PubMed]

2. Tonelli, M.; Wiebe, N.; Knoll, G.; Bello, A.; Browne, S.; Jadhav, D.; Klarenbach, S.; Gill, J. Systematic Review: Kidney Transplantation Compared With Dialysis in Clinically Relevant Outcomes. Arab. Archaeol. Epigr. 2011, 11, 2093-2109. [CrossRef]

3. Laupacis, A.; Keown, P.; Pus, N.; Krueger, H.; Ferguson, B.; Wong, C.; Muirhead, N. A study of the quality of life and cost-utility of renal transplantation. Kidney Int. 1996, 50, 235-242. [CrossRef]

4. Oterdoom, L.H.; De Vries, A.P.J.; Van Ree, R.M.; Gansevoort, R.T.; Van Son, W.J.; Van Der Heide, J.J.H.; Navis, G.; De Jong, P.E.; Gans, R.O.B.; Bakker, S.J.L. N-Terminal Pro-B-Type Natriuretic Peptide and Mortality in Renal Transplant Recipients Versus the General Population. Transplantation 2009, 87, 1562-1570. [CrossRef] [PubMed]

5. Kasiske, B.L.; Zeier, M.G.; Chapman, J.R.; Craig, J.C.; Ekberg, H.; Garvey, C.A.; Green, M.D.; Jha, V.; Josephson, M.A.; Kiberd, B.A.; et al. KDIGO clinical practice guideline for the care of kidney transplant recipients: A summary. Kidney Int. 2010, 77, 299-311. [CrossRef]

6. Gomes-Neto, A.W.; Sotomayor, C.G.; Pranger, I.G.; Berg, E.V.D.; Gans, R.O.B.; Soedamah-Muthu, S.S.; Navis, G.; Bakker, S.J.L. Intake of Marine-Derived Omega-3 Polyunsaturated Fatty Acids and Mortality in Renal Transplant Recipients. Nutrient 2017, 9, 363. [CrossRef]

7. Osté, M.C.J.; Gomes-Neto, A.W.; Corpeleijn, E.; Gans, R.O.B.; De Borst, M.H.; Berg, E.V.D.; Soedamah-Muthu, S.S.; Kromhout, D.; Navis, G.J.; Bakker, S.J.L. Dietary Approach to Stop Hypertension (DASH) diet and risk of renal function decline and all-cause mortality in renal transplant recipients. Arab. Archaeol. Epigr. 2018, 18, 2523-2533. [CrossRef] [PubMed] 
8. Gomes-Neto, A.W.; Osté, M.C.; Sotomayor, C.G.; Berg, E.V.D.; Geleijnse, J.M.; Berger, S.P.; Gans, R.O.; Bakker, S.J.L.; Navis, G.J. Mediterranean Style Diet and Kidney Function Loss in Kidney Transplant Recipients. Clin. J. Am. Soc. Nephrol. 2020, 15, 238-246. [CrossRef]

9. Gomes-Neto, A.W.; Osté, M.C.; Sotomayor, C.G.; vd Berg, E.; Geleijnse, J.M.; Gans, R.O.; Navis, G.J. Fruit and vegetable intake and risk of post trans plantation diabetes in renal transplant recipients. Diabetes Care 2019, 42, 1645-1652. [CrossRef]

10. Baia, L.; Berg, E.V.D.; Vervloet, M.; Heilberg, I.; Navis, G.; Bakker, S.; Geleijnse, J.; Kromhout, D.; Soedamah-Muthu, S.; De Borst, M.H. Fish and omega-3 fatty acid intake in relation to circulating fibroblast growth factor 23 levels in renal transplant recipients. Nutr. Metab. Cardiovasc. Dis. 2014, 24, 1310-1316. [CrossRef]

11. Baxmann, A.C.; Menon, V.B.; Pestana, J.L.; Carvalho, A.B.; Heilberg, I.P. Overweight and body fat are predictors of hypovitaminosis D in renal transplant patients. Clin. Kidney J. 2014, 8, 49-53. [CrossRef] [PubMed]

12. González, A.L.; Pérez, R.G.; Soto, J.B.; Castillo, R.F. Study of weight and body mass index on graft loss after transplant over 5 years of evolution. Int. J. Med Sci. 2020, 17, 2306-2311. [CrossRef] [PubMed]

13. Boslooper-Meulenbelt, K.; Patijn, O.; Battjes-Fries, M.C.E.; Haisma, H.; Pot, G.K.; Navis, G.J.; Meulenbelt, B.; Fries, B. Pot Barriers and Facilitators of Fruit and Vegetable Consumption in Renal Transplant Recipients, Family Members and Healthcare Professionals-A Focus Group Study. Nutrient 2019, 11, 2427. [CrossRef]

14. Donald, M.; Kahlon, B.K.; Beanlands, H.; Straus, S.; Ronksley, P.; Herrington, G.; Tong, A.; Grill, A.; Waldvogel, B.; Large, A.C.; et al. Self-management interventions for adults with chronic kidney disease: A scoping review. BMJ Open 2018, 8, e019814. [CrossRef] [PubMed]

15. Villinger, K.; Wahl, D.R.; Boeing, H.; Schupp, H.T.; Renner, B. The effectiveness of app-based mobile interventions on nutrition behaviours and nutrition-related health outcomes: A systematic review and meta-analysis. Obes. Rev. 2019, 20, 1465-1484. [CrossRef] [PubMed]

16. Heiden, S.; Buus, A.A.; Jensen, M.H.; Hejlesen, O.K. A diet management information and communication system to help chronic kidney patients cope with diet restrictions. Stud. Heal. Technol. informatics 2013, 192, 543-547.

17. Lambert, K.; Mullan, J.; Mansfield, K.; Owen, P. Should We Recommend Renal Diet-Related Apps to Our Patients? An Evaluation of the Quality and Health Literacy Demand of Renal Diet-Related Mobile Applications. J. Ren. Nutr. 2017, 27, 430-438. [CrossRef] [PubMed]

18. Ikizler, T.A.; Burrowes, J.D.; Byham-Gray, L.D.; Campbell, K.L.; Carrero, J.-J.; Chan, W.; Fouque, D.; Friedman, A.N.; Ghaddar, S.; Goldstein-Fuchs, D.J.; et al. KDOQI Clinical Practice Guideline for Nutrition in CKD: 2020 Update. Am. J. Kidney Dis. 2020, 76, S1-S107. [CrossRef]

19. Kosa, S.D.; Monize, J.; D’Souza, M.; Joshi, A.; Philip, K.; Reza, S.; Samra, S.; Serrago, B.; Thabane, L.; Gafni, A.; et al. Nutritional Mobile Applications for CKD Patients: Systematic Review. Kidney Int. Rep. 2019, 4, $399-407$. [CrossRef]

20. Browning, R.B.; McGillicuddy, J.W.; Treiber, F.A.; Taber, D.J. Kidney transplant recipients' attitudes about using mobile health technology for managing and monitoring medication therapy. J. Am. Pharm. Assoc. 2016, 56, 450-454. [CrossRef]

21. Van Klaveren, C.W.; De Jong, P.G.M.; Hendriks, A.R.; Luk, F.; De Vries, A.P.J.; Van Der Boog, P.J.M.; Reinders, M.E.J. Content, Delivery Modes, and Social-Epistemological Dimensions of Online Information for Renal Transplant Patients and Living Donors during the COVID-19 Pandemic: Lessons Learned (Preprint). J. Med. Internet Res. 2020. [CrossRef]

22. Humalda, J.K.; Klaassen, G.; De Vries, H.; Meuleman, Y.; Verschuur, L.C.; Straathof, E.J.; Laverman, G.D.; Bos, W.J.W.; Van Der Boog, P.J.; Vermeulen, K.M.; et al. A Self-management Approach for Dietary Sodium Restriction in Patients With CKD: A Randomized Controlled Trial. Am. J. Kidney Dis. 2020, 75, 847-856. [CrossRef]

23. Eldridge, A.L.; Piernas, C.; Illner, A.-K.; Gibney, M.J.; Gurinović, M.A.; De Vries, J.H.; Cade, J.E. Evaluation of New Technology-Based Tools for Dietary Intake Assessment-An ILSI Europe Dietary Intake and Exposure Task Force Evaluation. Nutrient 2018, 11, 55. [CrossRef] [PubMed] 
24. Rashidi, P.; Bihorac, A. Artificial intelligence approaches to improve kidney care. Nat. Rev. Nephrol. 2020, 16, 71-72. [CrossRef] [PubMed]

25. Thongprayoon, C.; Kaewput, W.; Kovvuru, K.; Hansrivijit, P.; Kanduri, S.R.; Bathini, T.; Chewcharat, A.; Leeaphorn, N.; Gonzalez-Suarez, M.L.; Cheungpasitporn, W. Promises of Big Data and Artificial Intelligence in Nephrology and Transplantation. J. Clin. Med. 2020, 9, 1107. [CrossRef] [PubMed]

Publisher's Note: MDPI stays neutral with regard to jurisdictional claims in published maps and institutional affiliations.

(C) 2020 by the authors. Licensee MDPI, Basel, Switzerland. This article is an open access article distributed under the terms and conditions of the Creative Commons Attribution (CC BY) license (http://creativecommons.org/licenses/by/4.0/). 